ISSN 1392-3196 / e-ISSN 2335-8947

Zemdirbyste-Agriculture, vol. 105, No. 3 (2018), p. 279-286

DOI $10.13080 / \mathrm{z}-\mathrm{a} .2018 .105 .036$

\title{
Preliminary evidence of the associations between DNA markers and morphological characters in sunflower under natural and salt stress conditions
}

\author{
Soheila AHMADPOUR ${ }^{1}$, Omid SOFALIAN ${ }^{1}$, Reza DARVISHZADEH ${ }^{2}$, Naser ABBASPOUR ${ }^{2}$ \\ ${ }^{1}$ University of Mohaghegh Ardabili \\ Ardabil, Iran \\ ${ }^{2}$ Urmia University \\ Urmia, Iran \\ E-mail: r.darvishzadeh@urmia.ac.ir
}

\begin{abstract}
Soil salinity is a serious threat to agricultural products worldwide. Agricultural biotechnology mainly aims at developing plants with higher tolerance in order to face the challenging environmental conditions, such as drought and salinity. Identification of marker-character associations is the first step towards marker-aided selection in plant improvement programs. In the current study, quantitative trait loci (QTLs), associated with salt tolerance, were identified using 84 common sunflower (Helianthus annuus L.) inbred lines, collected from different geographical origins. The lines were fingerprinted with 30 simple sequence repeat (SSR) markers. This generated 71 clear and scorable bands, $87 \%$ of which were polymorphic. Associations between SSR markers and 18 agronomic characters were analysed using mixed linear model (MLM). Based on SSR markers data, the association panel was subdivided into two subpopulations $(\mathrm{K}=2)$. About $2.06 \%$ of the 435 possible locus pairs of the studied SSRs represented significant linkage disequilibrium (LD). Six and 13 SSR loci showed significant $(P \leq 0.01)$ association with the assessed characters under natural and salt stress conditions, respectively. Several molecular markers were significantly associated with more than one phenotypic character, suggesting the possible presence of genetic linkage or pleiotropic effects. The identified and associated markers are expected to be helpful in marker-aided selection in sunflower breeding programmes.
\end{abstract}

Key words: abiotic stress, linkage disequilibrium, molecular markers, oil crops, quantitative trait loci mapping.

\section{Introduction}

Soil and water salinity is the main factor limiting growth and performance of field crops worldwide (Shahbaz, Ashraf, 2013). About 6\% (equivalent to 800 million hectares) of world's lands are affected by salt (Yang et al., 2011). It is estimated that from 230 million hectares of agricultural lands under irrigation, approximately $20 \%$ (equivalent to 45 million ha) are saline (Arzani, 2008). About $0.2-0.4 \%$ of the total cultivable lands are removed from plantation every year due to water logging and salinity problems (Makhdum, Ashfaq, 2008). Of the total land in Iran (162.2 million hectares), 23.8 million hectares are affected by salt (Arzani, 2008). Salt stress seriously affects the economy of country by limiting distribution of agricultural systems and crop productivity. The problem is increasing annually due to climatic change and poor irrigation management. Most cultivated plants are salt sensitive and, therefore, salinity is an ever-present threat to agricultural activity (Flowers, Flowers, 2005).
Most important effect of salt stress includes limiting water availability, disrupting ions balance that results in reduced growth and photosynthesis rate, increased free radicals, and discontinuance membrane actions, enzymes and cell metabolism activities (Ashraf, 2004).

Osmotic stress occurs rapidly in the initial phase of salt stress and ionic stress occurs slowly in the second phase at high levels of $\mathrm{NaCl}$, which results in plant cells death (Horie et al., 2012). The accumulation of salt around the root causes a very negative potential in soil, reducing water absorption by roots.

Cultivated common sunflower (Helianthus annuus $\mathrm{L}$.) is a diploid plant $(2 \mathrm{n}=2 \mathrm{x}=34)$ with a genome size of 2871 to $3189 \mathrm{Mbp}$ (Schilling, 2006). It is one of the most ancient oilseed species in North America and the fifth largest among the oilseed crops after soybean, rapeseed, cotton, and groundnut. Consumers prefer its oil due to high content of unsaturated fatty acids.

Please use the following format when citing the article:

Ahmadpour S., Sofalian O., Darvishzadeh R., Abbaspour N. 2018. Preliminary evidence of the associations between DNA markers and morphological characters in sunflower under natural and salt stress conditions. Zemdirbyste-Agriculture, 105 (3): $279-286$ DOI $10.13080 / \mathrm{z}-\mathrm{a} .2018 .105 .036$ 
Although sunflower is moderately tolerant to salt stress, its production is greatly affected by saline conditions (Pasda, Diepenbrock, 1990). Salinity induces an adverse effect on all growth parameters of sunflower (Hussain, Rehman, 1993). Plant height, leaf number and leaf area of sunflower decrease with increasing salinity and show a reduction of $22.9 \%$ and $37 \%$ in the above-mentioned characters at $10 \mathrm{dS} \mathrm{m}^{-1}$ electrical conductivity (EC) of media, respectively. Similarly, salinity stress significantly reduces yield and yield components of sunflower (Rehman, Hussain, 1998). Agricultural biotechnology mainly attempts to develop more tolerant crops in the challenging environmental conditions like salinity, drought, extreme temperature, and oxidative stress. Salt tolerance is a complex character controlled by several quantitative trait loci (QTLs) (Flowers, 2004). Moreover, identification of marker and character associations is considered as an important step towards marker-aided selection for salt tolerant breeding programs.

Microsatellite or simple sequence repeat (SSR) is found in the genomes of most eukaryotes. Their constant units mostly consist of two, three or four nucleotides. SSRs technology is based on amplification of repeated motif, via primers designed for flanking area. Their polymerase chain reaction (PCR) outputs are replicable in different labs around the world. SSRs - due to their co-dominant and multi-allelic behaviour, high polymorphic information content and random distribution in the genome, are suitable tools for genomic variation assessment and QTL mapping activity (Snowdon, Fried, 2004). Association analysis, as an alternative to linkage mapping, is a valuable tool for the dissection of QTLs controlling complex characters in crop plants. This approach detects associations between phenotype and genotype on the basis of linkage disequilibrium (LD) (Gajardo et al., 2015). Indeed, association analysis relies on LD between markers and QTLs present in the collections of diverse germplasm (Pritchard et al., 2000). It exploits the recombination events that occurred during the long evolutionary history (Nordborg, Tavare, 2002). Mandel et al. (2013) investigated population differentiation and LD structure in sunflower by single nucleotide polymorphism (SNP) markers. In attempts to analyse their association, numerous informative markers were identified for characters related to plant architecture and flowering time. There are a few reports on application of molecular markers in salt tolerance assessment in sunflower. Morsali et al. (2016) evaluated a population of sunflower recombinant inbred lines (RILs) for yield and yield components under saline and normal conditions. They identified 14 and 17 QTLs for the studied characters in normal and salt stress conditions, respectively. In their QTL mapping attempts the highest amount of $R^{2}$ $(7.33 \%)$, related to QTL, was identified for number of days to flowering character under salt stress conditions. They detected a number of co-localized QTLs for some studied traits under normal and salt stress conditions, which augment the efficiency of marker-aided selection in plant breeding programs. Zhao et al. (2016) performed association analysis for salt tolerance related characters in cotton (Gossypium hirsutum L.) using 74 SSR markers. They found eight markers significantly associated with characters with $R^{2}$ values, ranging from $2.91 \%$ to $7.82 \%$ with an average of $4.32 \%$. Darvishzadeh (2016) investigated the population structure and LD among 106 dispersed sunflower genotypes by microsatellite, interretrotransposon amplified polymorphism (IRAP) and retrotransposon-microsatellite amplified polymorphism
(REMAP) markers. He identified some informative markers for agro-morphological characters via mixed liner modelling analysis. In his study, high genetic variability was observed among sunflower genotypes in view of studied agro-morphological characters and amplified molecular markers.

Microsatellite markers due to the above mentioned advantage have high potential for improving salt tolerance in sunflower. The aim of the present study was to identify microsatellite markers linked to morphological characters in sunflower in natural and salt stress conditions. The study would be based on two consecutive years' data on 84 oily sunflower lines collected from different geographical regions of the world. Introduction and identification of specific DNA markers associated with salt tolerance-related characters will assist sunflower breeders in the selection of salt tolerant genotypes, accelerating and facilitating breeding activities under saline conditions.

\section{Materials and methods}

Plant materials and phenotyping. A total of 84 inbred lines of common sunflower (Helianthus annuus L.) from different geographical origins (Table 1) were evaluated in randomized complete block designs with three replications in pot conditions. The lines were evaluated during the period of 2014-2015 under natural and salt stress $\left(8 \mathrm{dS} \mathrm{m}^{-1}\right)$ conditions outside the greenhouse in an open air area in Urmia University, Iran. Lines were individually grown in $24 \times 24 \mathrm{~cm}^{2}$ plastic pots, containing a mixture of $40 \%$ soil, $40 \%$ compost and $20 \%$ sand, as described in Poormohammad Kiani et al. (2007). Salinity stress was applied with $\mathrm{NaCl}$. Based on the primary amount of soil salinity, a solution with 0.4 molar $\mathrm{NaCl}$ was prepared in order to achieve $8 \mathrm{dS} \mathrm{m}^{-1}$ $\mathrm{NaCl}$. About $500 \mathrm{ml}$ of solution was added to each pot at 8-leaf stage / code 18 on the $\mathrm{BBCH}$ scale. To avoid osmotic stress, the saline solution was added in two steps: $250 \mathrm{ml}$ of solution was added in the morning and the rest applied in the afternoon. Soil salinity was controlled by electrical conductivity-meter during the experiment. A drip irrigation system was used and fertilization was carried out several times during the vegetative growth period. During irrigation, care was taken so that water did not drain out from the pots.

After flowering and harvesting of capitulum, some agro-morphological characters per plant were measured. The characters included leaf number, stem diameter, plant height, head diameter, upper leaf length, upper leaf width, upper petiole length, middle leaf length, middle leaf width, middle petiole length, bottom leaf length, bottom leaf width, bottom petiole length, chlorophyll index (SPAD), head dried weight, one hundred seed weight and grain yield. Number of days from planting to flowering was also recorded in each pot. Plants were harvested at physiological maturity stage. The chlorophyll concentrations were measured from the middle of the youngest fully expanded leaves. For the measurement of chlorophyll at the mentioned locations, a chlorophyll meter SPAD-502 (Minolta, Japan) was used. Furthermore, the values were averaged before entering them into the statistical analysis. The measurements were performed for both natural and salt stress conditions.

Simple sequence repeat (SSR) data used in the present study were provided by Sahranavard et al. (2015). Genomic DNA was extracted from the young leaves of 15-day-old seedlings. DNA quality was 
Table 1. The origin and site description of oily sunflower inbred lines used in the present study

\begin{tabular}{|c|c|c|c|c|c|c|c|}
\hline Code & Line name & Origin & Research centre & Code & Line name & Origin & Research centre \\
\hline 1 & H100A/83HR4 & France & ASGROW & 43 & CSWW2X & France & IFVC \\
\hline 2 & H209A/LC1064 & France & ASGROW & 44 & $1009370-3(100 \mathrm{~K})$ & France & ENSAT \\
\hline 3 & $\mathrm{H} 205 \mathrm{~A} / \mathrm{H} 543 \mathrm{R}$ & France & ASGROW & 45 & $\mathrm{H} 100 \mathrm{~A}$ & France & ASGROW \\
\hline 4 & AS5306 & France & ENSAT & 46 & 15031 & France & ASGROW \\
\hline 5 & RHA858 & USA & USDA & 47 & H205A/83HR4 & France & ASGROW \\
\hline 6 & H209A/83HR4 & France & ASGROW & 48 & RHA265 & USA & USDA \\
\hline 7 & as3211 & France & ENSAT & 49 & PM1-3 & USA & USDA \\
\hline 8 & 254-ENSAT & France & ENSAT & 50 & RT948 & France & RUSTICA \\
\hline 9 & AS5304 & France & ASGROW & 51 & 283-ENSAT & - & - \\
\hline 10 & $1009329.2(100 \mathrm{~K})$ & France & ENSAT & 52 & QHP-1 & France & INRAMONT \\
\hline 11 & 270-ENSAT & France & ENSAT & 53 & SDR19 & USA & USDA \\
\hline 12 & AS613 & France & ASGROW & 54 & HA337B & USA & USDA \\
\hline 13 & A-F1POPA & France & NOVARTIS & 55 & H100B & France & ASGROW \\
\hline 14 & OES & France & INRAMONT & 56 & B454/03 & Hungary & - \\
\hline 15 & H100A/LC1064 & France & ASGROW & 57 & HA304 & USA & USDA \\
\hline 16 & RHA266 & USA & USDA & 58 & RT931 & France & RUSTICA \\
\hline 17 & $\mathrm{PAC} 2$ & France & ENSAT & 59 & HA335B & USA & USDA \\
\hline 18 & H157A/LC1064 & France & ASGROW & 60 & SDB3 & USA & USDA \\
\hline 19 & 5DES20QR & France & $\mathrm{BRN}$ & 61 & LC1064C & France & ASGROW \\
\hline 20 & $1009337(100 \mathrm{~K})$ & France & ENSAT & 62 & NS-R5 & France & NOVARTIS \\
\hline 21 & AS3232 & France & ENSAT & 63 & H156A/RHA274 & France & ASGROW \\
\hline 22 & $12 \mathrm{ASB} 3$ & France & ASGROW & 64 & SDB1 & USA & USDA \\
\hline 23 & 8ASB2 & France & ASGROW & 65 & HAR-4 & USA & USDA \\
\hline 24 & $9 \mathrm{CSA} 3$ & France & Caussade & 66 & AS5305 & France & ASGROW \\
\hline 25 & H049+FSB & France & - & 67 & RHA274 & USA & USDA \\
\hline 26 & $5 \mathrm{AS}-\mathrm{F} 1 / \mathrm{A} 2 \times \mathrm{R} 2$ & France & ASGROW & 68 & H100A/RHA274 & France & ASGROW \\
\hline 27 & 7CR16=PRH6 & France & ASGROW & 69 & H209A/H566R & France & ASGROW \\
\hline 28 & ENSAT699 & France & C.F & 70 & ASO-1-POP-A & France & ENSAT \\
\hline 29 & SSD-581 & France & ENSAT & 71 & AS6305 & France & ENSAT \\
\hline 30 & TMB-51 & France & ASGROW & 72 & D34 & USA & USDA \\
\hline 31 & 110 & Iran & INRAMONT & 73 & CAY & France & ENSAT \\
\hline 32 & H603R & France & SPII & 74 & 346 & Iran & SPII \\
\hline 33 & 4 & Iran & SPII & 75 & NS-F1-A5×R5 & France & NOVARTIS \\
\hline 34 & 703-CHLORINA & France & INRAMONT & 76 & 36 & Iran & SPII \\
\hline 35 & NSF1-A4×R5 & France & SPII & 77 & 38 & Iran & SPII \\
\hline 36 & 28 & Iran & ENSAT & 78 & SDB2 & France & INRAMONT \\
\hline 37 & 30 & Iran & NOVARTIS & 79 & H158A/LC1064 & - & - \\
\hline 38 & F1250/03 & Hungary & SPII & 80 & H156A/H543R & France & ASGROW \\
\hline 39 & SDR18 & USA & SPII & 81 & H543R/H543R & France & ASGROW \\
\hline 40 & LP-CSYB & France & - & 82 & H543R & France & - \\
\hline 41 & $803-1$ & Serbia & USDA & 83 & 15038 & France & ASGROW \\
\hline 42 & $1009370-1(100 \mathrm{~K})$ & France & ENSAT & & & & \\
\hline
\end{tabular}

checked by running $1 \mathrm{~mL}$ DNA in $0.8 \%(\mathrm{w} / \mathrm{v})$ agarose gels in $0.5 \times$ TBE (Tris-borate-EDTA) buffer: $45 \mathrm{mmol} \mathrm{L}^{-1}$ Tris base, $45 \mathrm{mmol} \mathrm{L}^{-1}$ boric acid, $1 \mathrm{mmol} \mathrm{L}^{-1}$ EDTA (ethylenediaminetetraacetic acid), $\mathrm{pH} 8.0$, at $80 \mathrm{~V}$ for 45 minutes. DNA samples that gave a smear in the gel were discarded. A total of 30 microsatellite markers (out of 339 ORS (Oregon State University) SSR markers) were used for DNA fingerprinting (Table 2). Polymerase chain reaction (PCR) for SSR markers was performed in a volume of $15 \mu \mathrm{l}$. The reaction mixture contained the following: $2.5 \mathrm{mmol} \mathrm{L}^{-1}$ of each primer, $0.4 \mathrm{U}$ of Taq DNA polymerase (Cinagene Co., Iran), $0.8 \mu \mathrm{l}$ of each dNTP (deoxyribonucleoside triphosphate) (BioFluxbiotech), $2 \mu \mathrm{l}$ of $10 \times$ PCR buffer, $0.16 \mu \mathrm{l} \mathrm{MgCl}$ (Cinagene Co.), $\mathrm{ddH}_{2} \mathrm{O}$, and $5 \mathrm{ng}$ of template DNA. Touchdown PCR was used for amplification of SSRs, which is as follows: $94^{\circ} \mathrm{C}\left(3^{\prime}\right)+1$ cycle $\left[\left(94^{\circ} \mathrm{C}\left(30^{\prime \prime}\right)+64^{\circ} \mathrm{C}\left(30^{\prime \prime}\right)+72^{\circ} \mathrm{C}\right.\right.$ $\left.\left(30^{\prime \prime}\right)\right]$. This was followed by 10 cycles, with a decrease in annealing temperature with $1^{\circ} \mathrm{C}$ per cycle +30 cycles $\left[\left(94^{\circ} \mathrm{C}\left(30^{\prime \prime}\right)+54^{\circ} \mathrm{C}\left(30^{\prime \prime}\right)+72^{\circ} \mathrm{C}\left(45^{\prime \prime}\right)\right]+72^{\circ} \mathrm{C}\left(10^{\prime}\right)\right.$. The reaction products were mixed with an equal volume of formamide dyes and resolved in a 3\% (w/v) agarose gel (Invitrogen, France) in $0.5 \times$ TBE buffer. Those were stained with $1.0 \mathrm{mg} \mathrm{mL}^{-1}$ ethidium bromide and photographed under UV light, using an image analysis system Gel-Doc (Gel Logic 212 PRO, USA).

Data analysis and association mapping. Normality test were done by procedure Proc Univariate in the $S A S$, version 9.2 and there was no need to transform the data. Descriptive statistics, such as mean, standard error, and coefficient of variation, for each studied character were calculated by using software $S A S$.

The effective analysis of population structure and detection of mixed genotypes were carried out using Bayesian method implemented in the software package of STRUCTURE, version 2.3.4 (Pritchard et al., 2000). The number of initial subpopulations $(\mathrm{K})$ was considered from 1-20 and with 10 replications for each run. Length of the burn-in period and Markov chain Monte Carlo (MCMC) replication number were set to 100,000 . The admixture model and correlated allele frequencies were chosen. The actual number of subpopulations was determined by: 1) the logarithm of likelihood for each $\mathrm{K} ; \mathrm{Ln} \mathrm{P}(\mathrm{D})=\mathrm{L}(\mathrm{K})$ (Rosenberg et al., 2002), and 2) the 
Table 2. Primer sequences of 30 simple sequence repeat (SSR) loci and their positions on sunflower genetic linkage map used for fingerprinting of sunflower lines

\begin{tabular}{|c|c|c|c|c|}
\hline Primer & Forward sequence $5^{\prime} \rightarrow 3^{\prime}$ & Reverse sequence $5^{\prime} \rightarrow 3^{\prime}$ & Linkage group & Position (cM) \\
\hline ORS785 & CAAAATACCCAGGTCAAAGCA & CCTAGCTTATGGGACGTATGGA & LG4 & 53.8 \\
\hline ORS807 & CCGATATTTTGACCGATATTTTGC & ТСТСАСССТТСАТСТССТТСС & LG16 & 67.9 \\
\hline ORS608 & CATGGAAAGCCGAGTTCTCT & CGTGCGTGATTAACATACCC & LG6 & 44.7 \\
\hline ORS609 & GCGAAGGAACTGAACCGATA & GGATTTTAGTCCGCCAATCA & LG12 & 56.0 \\
\hline ORS1079 & TACGACTGACGATTCCATTTCTC & AACTGGATTTCACAGGGAGTGTT & LG14 & 14.4 \\
\hline ORS718 & CACTTTACGCACACCAAACC & ATGCAACACCCGAATCAAA G & LG3 & 30.2 \\
\hline ORS1265 & GGGTTTAGCAAATAATAGGCACA & ACCCTTGGAGTTTAGGGATCA & LG9 & 25.0 \\
\hline ORS949 & TGCAAGGTATCCATATTCCACAA & TATACGCACCGGAAAGAAAGTC & LG3 & 38.7 \\
\hline ORS378 & GTGAAACCTTCGGACCTCTG & GTACAAAACTTATAAATAAAACAATA & LG16 & 86.3 \\
\hline ORS694 & CCTGGAACTGAACCGAGAAC & GCCGTGAAACAGAGAGAGGA & LG14 & 35.8 \\
\hline ORS621 & CGCCTTATGCTGAGAGGAAA & CCTGAAGCGAAGAAGAATCG & LG11 & 1.1 \\
\hline ORS488 & СССАТТСАСТССТGTTТССА & CTCCGGTGAGGATTTGGAT T & LG3 & 67.2 \\
\hline ORS728 & СТCСATAGCAACСАССТGAAA & ССАAАСТCTGAATGATACTTGTGAC & LG1 & 25.2 \\
\hline ORS844 & ACGATGCAAAGAATATACTGCAC & CATGTTTAATAGGTTTTAATTCTAGGG & LG9 & 75.5 \\
\hline ORS878 & TGCAAGGTATCCATATTCCACAA & TATACGCACCGGAAAGAAAGTC & LG10 & 29.9 \\
\hline ORS1179 & GATTCGGAGCTGTTAGGAGGTAG & AAACGGGAAGCAAGAATAGAACA & LG13 & 60.1 \\
\hline ORS1215 & ATACТСТТССАСССТСАААТССА & GGTTGCGGTAGTGGTCTGTAGT & LG15 & 74.8 \\
\hline ORS822 & CAATGCCATCTGTCATCAGCTAC & AAACAAACCTTTGGACGAAACTC & LG3 & 69.0 \\
\hline ORS1256 & GATGTTGATGTTGGTGAAGTTGC & CTCCGTCACCTTAAGCACTTGTA & LG6 & 68.4 \\
\hline ORS1088 & ACTATCGAACCTCCСТCCAAAC & GGATTTCTTTCATCTTTGTGGTG & LG10 & 49.0 \\
\hline ORS617 & GGTACTTGGTATTCATGGGTCAT & GACACCGCCAACTTAACACTT & LG9 & 92.3 \\
\hline ORS1064 & TGAATGATCTATGAGTGGTGATGG & ACTCGCAGTGGTAAGTCGTTAGG & LG16 & 13.7 \\
\hline ORS1209 & AACAAGCAAGCAAATCAACCATA & AGAATTAAACCCAACCCGGAAC & LG10 & 27.0 \\
\hline ORS1264 & TAGAAGCGGTTGGGTTGACAGTA & TGAACTCGGTTGATTCTCTAGCC & LG2 & 15.7 \\
\hline ORS1242 & GCAATCGTTTCACTCTTCCATTC & TGGTCGTAGAATTGTCGGTCAT & LG15 & 63.3 \\
\hline ORS630 & TGTGCTGAGGATGATATGCAG & GCACGACCCGGATATGTAAC & LG13 & 44.2 \\
\hline ORS733 & TATGAGTTGGCAAGGGCTTC & GGACTCCAACGAGAGAATCAGT & LG11 & 0.0 \\
\hline ORS565 & TGGTCAACGGATTTAGAGTCAA & TCCAGTTTGGTCTTGATTTGG & - & - \\
\hline HA3040 & GACCCGAACCACACT & GTTCTTGCTTCGATCC & - & - \\
\hline HS3070 & GGGATGAGCTCTGTC & СTTTTCAATTCCCGCT & - & - \\
\hline
\end{tabular}

LG - linkage group, cM - centimorgan

statistic Delta $K(\Delta K)$, which is based on secondary rate of changes in likelihood; $\Delta \mathrm{K}=[\mathrm{L} "(\mathrm{~K})] /$ Stdev (Evanno et al., 2005). In this method, the probability of slope breaks at the point where the number of hypothetical $\mathrm{K}$ is at the maximum point of likelihood. Association analysis was performed in TASSEL 2.1, using kinship (K-matrix) and ancestry coefficients ( $Q$ values) as covariates in mixed linear model (MLM).

\section{Results and discussion}

Phenotypic diversity. The basic statistics such as mean, range, standard deviation and coefficient of variation for studied characters in sunflower lines were summarized in Table 3. Maximum reduction was observed in the plant height, chlorophyll index, leaf number and grain yield. Reduction of leaf area and consequent decrease in the chlorophyll content of sunflower leaves under saline state were reported by other researchers (Anwar-ul-Haq et al., 2013). The maximum genotypic and phenotypic coefficients of variation were observed for head (capitulum) dried weight $(0.41,0.67)$ and upper petiole length $(0.20,0.44)$ in natural and salt stress conditions, respectively. The minimum genotypic and phenotypic coefficients of variation were observed for days to flowering as $0.03,0.07$ and $0.05,0.08$, respectively, both in natural and salt stress conditions (Table 3).

The highest heritability value in natural conditions was observed for 100-seed weight (79\%) and plant height $(79 \%)$ and the lowest one was observed for bottom leaf width. The highest heritability value in salt stress states was observed for stem diameter $(0.7)$ and the lowest one was observed for bottom leaf length (0.21) (Table 3). Heritability is the ratio of genotypic to phenotypic variations. Characters with higher heritability can be more easily changed through selection. When heritability is high, phenotypic value is a good estimator of genotypic value. Overall, the heritability values were lower under salt stress conditions than under natural conditions. This shows that heritability increases in a better environment. Probably, this results from the effect of environment on genotypes under salt stress states. Similar results were reported regarding yield components' heritabilities in faba bean under drought stress conditions (Toker, 2004). The high phenotypic variations among studied sunflower lines indicated the suitability of present population for association analysis of salt related characters.

Genomic diversity and population structure. Using 30 SSR primer pairs, 71 alleles were generated, of which $87 \%$ were polymorphic. In the collection under investigation (association panel), $2.06 \%$ of the possible SSR locus pairs $([n(n-1) / 2]=[30(30-1) / 2]=$ 435 pairs) displayed a significant linkage disequilibrium (LD) $(P<0.01)$ (data not shown). LD presents the nonrandom correlation of alleles at different genetic loci on a single chromosome (Mackay, Powell, 2007). Several factors play important role in establishing the haplotype LD blocks in genome (Stich et al., 2005; Oraguzie et al., 2007). Out of which, mutation and recombination are the key factors affecting LD significantly. Effective analysis of the population structure and accurate classification of individuals into appropriate subpopulations were performed via Bayesian method implemented in the software STRUCTURE. This model-based clustering 
Table 3. Descriptive statistics for agronomic characters in sunflower inbred lines evaluated under natural (NC) and salt stress (SSC) conditions

\begin{tabular}{|c|c|c|c|c|c|c|c|c|c|c|c|c|c|c|}
\hline \multirow{3}{*}{ Trait } & \multicolumn{14}{|c|}{ Item } \\
\hline & \multicolumn{2}{|c|}{ Mean } & \multicolumn{2}{|c|}{ SD } & \multicolumn{2}{|c|}{$\mathrm{Vg}$} & \multicolumn{2}{|c|}{ Vphe } & \multicolumn{2}{|c|}{$\mathrm{H}^{2}$} & \multicolumn{2}{|c|}{$\mathrm{CVg}$} & \multicolumn{2}{|c|}{ CVphe } \\
\hline & $\mathrm{NC}$ & $\mathrm{SSC}$ & $\mathrm{NC}$ & $\mathrm{SSC}$ & $\mathrm{NC}$ & $\mathrm{SSC}$ & $\mathrm{NC}$ & $\mathrm{SSC}$ & $\mathrm{NC}$ & $\mathrm{SSC}$ & $\mathrm{NC}$ & $\mathrm{SSC}$ & $\mathrm{NC}$ & SSC \\
\hline Days to flowering & 78.1 & 77.6 & 5.5 & 6.3 & 6.6 & 14.4 & 28.3 & 40.3 & 0.46 & 0.61 & 0.0 & 0.1 & 0.1 & 0.1 \\
\hline Leaf number & 20.4 & 18.0 & 4.6 & 4.6 & 6.0 & 5.8 & 16.6 & 16.9 & 0.61 & 0.6 & 0.1 & 0.1 & 0.2 & 0.2 \\
\hline Stem diameter & 11.8 & 11.3 & 2.4 & 1.9 & 2.5 & 1.6 & 5.5 & 3.5 & 0.7 & 0.7 & 0.1 & 0.1 & 0.2 & 0.2 \\
\hline Head diameter & 9.1 & 8.5 & 2.5 & 2.2 & 2.8 & 1.4 & 6.4 & 4.7 & 0.69 & 0.54 & 0.2 & 0.1 & 0.3 & 0.3 \\
\hline Plant height & 92.6 & 80.2 & 18.8 & 16.2 & 186 & 78.9 & 324 & 242 & 0.79 & 0.58 & 0.2 & 0.1 & 0.2 & 0.2 \\
\hline Upper leaf length & 8.3 & 7.4 & 2.3 & 2.1 & 1.1 & 0.7 & 4.6 & 3.9 & 0.47 & 0.38 & 0.1 & 0.1 & 0.3 & 0.3 \\
\hline Upper leaf width & 5.2 & 4.8 & 2.0 & 2.0 & 0.7 & 0.4 & 3.6 & 3.4 & 0.43 & 0.27 & 0.2 & 0.1 & 0.4 & 0.4 \\
\hline Upper petiole length & 3.1 & 2.6 & 1.3 & 1.2 & 0.4 & 0.3 & 1.4 & 1.4 & 0.53 & 0.42 & 0.2 & 0.2 & 0.4 & 0.4 \\
\hline Central leaf length & 13.0 & 12.2 & 2.8 & 2.3 & 2.5 & 0.9 & 7.3 & 4.9 & 0.59 & 0.38 & 0.1 & 0.1 & 0.2 & 0.2 \\
\hline Central leaf width & 10.8 & 10.2 & 2.9 & 2.3 & 2.7 & 0.6 & 7.1 & 5.1 & 0.64 & 0.26 & 0.2 & 0.1 & 0.3 & 0.2 \\
\hline Central petioles length & 8.3 & 7.4 & 2.0 & 1.9 & 1.5 & 0.6 & 4.1 & 3.5 & 0.61 & 0.38 & 0.2 & 0.1 & 0.3 & 0.3 \\
\hline Bottom leaf length & 7.8 & 7.9 & 2.1 & 2.4 & 0.3 & 0.4 & 3.3 & 5.0 & 0.23 & 0.21 & 0.1 & 0.1 & 0.2 & 0.3 \\
\hline Bottom leaf width & 5.1 & 5.4 & 2.1 & 2.5 & 0.1 & 0.5 & 3.2 & 5.1 & 0.1 & 0.24 & 0.1 & 0.1 & 0.4 & 0.4 \\
\hline Bottom petiole length & 6.4 & 6.5 & 2.0 & 2.2 & 0.9 & 0.9 & 3.6 & 4.7 & 0.47 & 0.41 & 0.1 & 0.2 & 0.3 & 0.3 \\
\hline Chlorophyll index & 38.2 & 28.6 & 5.3 & 4.9 & 9.1 & 7.6 & 28.4 & 23.4 & 0.57 & 0.58 & 0.1 & 0.1 & 0.1 & 0.2 \\
\hline Head dried weight & 11.8 & 12.4 & 7.9 & 7.5 & 23.0 & 17.8 & 61.9 & 53.4 & 0.63 & 0.59 & 0.4 & 0.3 & 0.7 & 0.6 \\
\hline Grain yield per plant & 25.9 & 24.0 & 9.5 & 8.1 & 34.1 & 17.7 & 88.7 & 65.5 & 0.64 & 0.51 & 0.2 & 0.2 & 0.4 & 0.3 \\
\hline 100-seed weight & 4.6 & 3.9 & 1.7 & 1.6 & 1.7 & 0.8 & 2.9 & 2.5 & 0.79 & 0.59 & 0.3 & 0.2 & 0.4 & 0.3 \\
\hline
\end{tabular}

$\mathrm{SD}$ - standard deviation, $\mathrm{Vg}$ - genotypic variance, $\mathrm{Vphe}$ - phenotypic variance, $\mathrm{H}^{2}$ - heritability, $\mathrm{CVg}$ - genotypic coefficient of variation, CVphe - phenotypic coefficient of variation

method is based on the allocation of individual to $\mathrm{K}$ clusters in such a way that Hardy-Weinberg equilibrium and linkage equilibrium are established within clusters. However, these kinds of equilibrium are absent between clusters. Maximum value of $\Delta \mathrm{K}$ was observed in $\mathrm{K}=2$.
Therefore, the studied panel probably consisted of two subpopulations (Fig.). Out of 84 studied sunflower lines, 12 lines showed mixed structure and 72 lines belonged to each one of first (36) and second (36) subgroups.
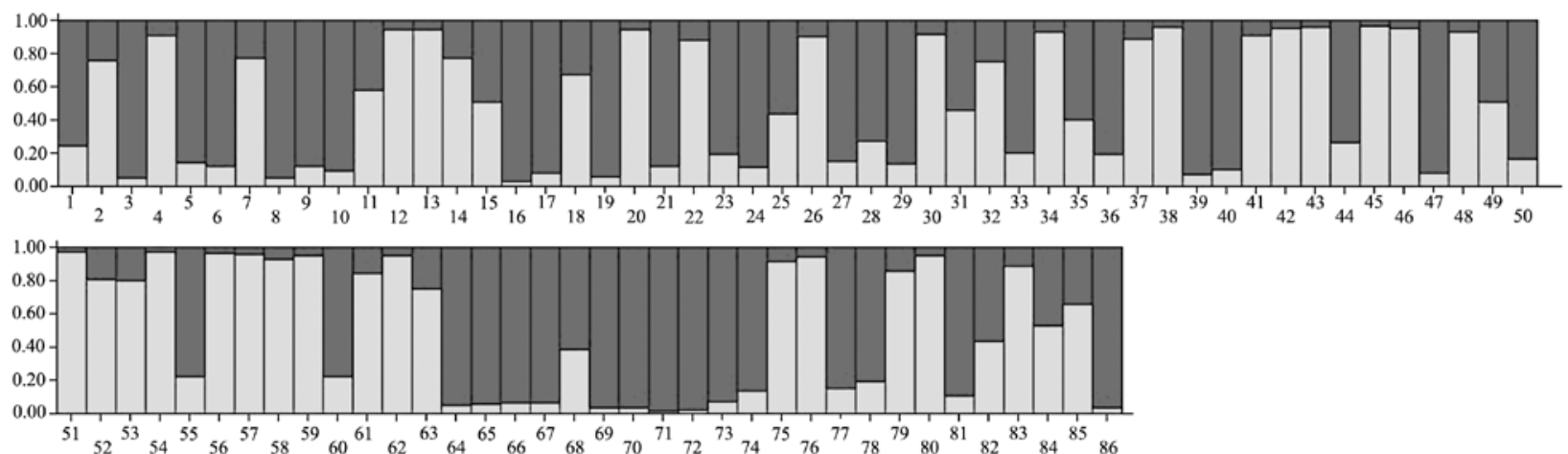

Note. Numbers on y-axis show the membership coefficient to sub-populations and numbers on $\mathrm{x}$-axis show the individual code that belongs to sunflower populations.

Figure. Genetic relatedness of sunflower lines identified in software STRUCTURE

Based on the data obtained from the genetic diversity and population structure analysis, the studied association panel had a diverse genetic variation and was, thus, suitable for the association analysis.

Association analysis. The significant level of LD found in this study supported the idea of using natural populations for genomic studies. Association studies are affected by the problem of false positive rates coming from population structure and genetic relationships among individuals. This results from various factors such as admixture, migration and historical pedigree relationships. Theoretically, kinship creates LD not only between genetically linked loci but also between genetically unlinked loci when predominant parents are included in the population. In maize, kinship equally generated LD between genetically linked and unlinked loci (Stich et al., 2005). One of the main advantages of linear models is the promise of improved resolution by considering subpopulation and kinship effects in association model (Breseghello, Sorrells, 2006). Association tests between SSR markers and studied traits were performed using mixed linear models implemented in TASSEL software (Bradbury et al., 2007). The $P$-value determined whether a character was linked with a marker significantly or not. The MLM could remove most of the false positives by incorporation kinship coefficients (K-matrix) and ancestry coefficient (Q values) estimates as covariates in the association model (Saeed et al., 2014). Several SSR loci associated with genes controlling character were identified. A total of 6 and 13 
significant $(P<0.01)$ marker-character associations were detected by MLM in natural and salt stress conditions, respectively (Table 4). However, P822 was associated with head diameter, P878 and P844 with plant height, P822 with chlorophyll and P949 with 100-seed weight.
Some markers were associated with characters under both natural and salt stress conditions. For instance, the SSR marker P608 was associated with more than one character such as days to flowering, leaf number, central leaf width, head dried weight, and 100-seed weight under

Table 4. Simple sequence repeat (SSR) loci identified for studied characters in sunflower inbred lines under natural and salt stress conditions using mixed linear model (MLM)

\begin{tabular}{|c|c|c|c|c|c|}
\hline \multirow{2}{*}{ Character } & \multirow{2}{*}{ SSR marker } & \multicolumn{2}{|c|}{ Natural conditions } & \multicolumn{2}{|c|}{ Salt stress conditions } \\
\hline & & $P$-value & $F$-value & $P$-value & $F$-value \\
\hline \multirow{3}{*}{ Days to flowering } & P608 & 0.0184 & 5.8197 & 0.0053 & 8.2832 \\
\hline & P718 & 0.0262 & 5.1677 & 0.0097 & 7.0859 \\
\hline & P694 & - & - & 0.0052 & 5.6676 \\
\hline \multirow{2}{*}{ Leaf number } & P608 & 0.0093 & 7.1542 & 0.000047 & 18.7964 \\
\hline & P718 & 0.0106 & 6.9066 & 0.0128 & 6.5413 \\
\hline \multirow{4}{*}{ Stem diameter } & P608 & - & - & 0.000126 & 16.4525 \\
\hline & P694 & 0.047 & 3.19430 & - & - \\
\hline & P822 & - & - & 0.0223 & 2.8119 \\
\hline & P1079 & - & - & 0.0421 & 3.3138 \\
\hline \multirow{4}{*}{ Head diameter } & P728 & 0.0105 & 4.8929 & - & - \\
\hline & P630 & 0.0423 & 2.6118 & - & - \\
\hline & P304 & - & - & 0.0495 & 2.1105 \\
\hline & P694 & - & - & 0.0498 & 3.132 \\
\hline \multirow{4}{*}{ Plant height } & P878 & 0.0302 & 3.6934 & - & - \\
\hline & P630 & - & - & 0.0493 & 2.5105 \\
\hline & P378 & - & - & 0.0246 & 3.9465 \\
\hline & P844 & - & - & 0.0112 & 4.7826 \\
\hline Upper leaf length & P718 & - & - & 0.043 & 4.2546 \\
\hline \multirow{3}{*}{ Upper leaf width } & P488 & - & - & 0.0098 & 7.1035 \\
\hline & P378 & - & - & 0.0065 & 5.4827 \\
\hline & P996 & - & - & 0.0428 & 3.3084 \\
\hline \multirow{3}{*}{ Upper petiole length } & P1179 & 0.0133 & 6.4599 & 0.0379 & 4.4842 \\
\hline & P694 & 0.0378 & 3.4315 & 0.0114 & 4.7727 \\
\hline & P378 & - & - & 0.0338 & 3.59 \\
\hline \multirow{3}{*}{ Central leaf length } & P608 & 0.0025 & 9.7988 & - & - \\
\hline & P1088 & 0.0402 & 4.3565 & - & - \\
\hline & P718 & - & - & 0.0391 & 4.4275 \\
\hline \multirow{2}{*}{ Central leaf width } & P608 & 0.0011 & 11.4753 & 0.0479 & 4.0531 \\
\hline & P565 & - & - & 0.027 & 3.8879 \\
\hline \multirow{2}{*}{ Central leaf width } & P608 & 0.0011 & 11.4753 & 0.0479 & 4.0531 \\
\hline & P565 & - & - & 0.027 & 3.8879 \\
\hline \multirow{3}{*}{ Central petioles length } & P1179 & 0.0454 & 4.1522 & 0.000883 & 12.1018 \\
\hline & P378 & 0.0495 & 3.1624 & - & - \\
\hline & P1265 & - & - & 0.0096 & 4.9418 \\
\hline Bottom leaf length & P996 & 0.0468 & 3.2082 & - & - \\
\hline \multirow{2}{*}{ Bottom leaf width } & P304 & - & - & 0.03 & 2.3399 \\
\hline & P565 & - & - & 0.0473 & 3.2452 \\
\hline \multirow{4}{*}{ Bottom petiole length } & P1265 & 0.0454 & 3.2221 & 0.0342 & 3.5325 \\
\hline & P996 & 0.0246 & 3.9216 & - & - \\
\hline & P378 & - & - & 0.0327 & 3.625 \\
\hline & P718 & - & - & 0.041 & 4.3429 \\
\hline \multirow{2}{*}{ Chlorophyll } & P822 & 0.0170 & 2.9676 & - & - \\
\hline & P630 & 0.0016 & 3.4005 & 0.0016 & 4.8494 \\
\hline \multirow{3}{*}{ Head dried weight } & P608 & 0.0037 & 8.9907 & 0.0014 & 11.1238 \\
\hline & P1256 & - & - & 0.0113 & 6.7372 \\
\hline & P621 & - & - & 0.0337 & 3.5667 \\
\hline \multirow{2}{*}{ Grain yield per plant } & P630 & - & - & 0.0048 & 4.092 \\
\hline & P1079 & - & - & 0.0199 & 4.1395 \\
\hline & P608 & 0.0002154 & 15.239 & 0.0000063 & 23.8091 \\
\hline 100 seed weight & P949 & 0.0286 & 3.7373 & - & - \\
\hline & P307 & - & - & 0.0304 & 2.8399 \\
\hline
\end{tabular}

both natural and salt stress conditions. Marker P718 was associated with days to flowering and leaf number, P1179 - with central petioles length and upper petiole length both in natural and salt stress conditions. Common markers between characters can be due to pleiotropic effects or linkage between genomic regions, involved in controlling characters (Jun et al., 2008). Identifying common markers is of great importance in plant breeding because it makes possible simultaneous selection of multiple characters. Basirnia et al. (2014) used MLM procedure to determine the SSR associated with chloride accumulation rate in oriental-type tobacco genotypes. Morsali et al. (2015) used a linkage map comprising 221 molecular markers (210 SSR/11 SNP) to identify genomic regions associated with physiological traits in sunflower under salinity stress conditions. Sahranavard et al. (2015) used general linear model (GLM) and mixed linear model (MLM) association models to 
identify some microsatellite markers associated with agro-morphological characters in 106 sunflower lines under normal conditions. These studies accelerated the application of molecular markers in sunflower improvement programs to some extent. Association analysis was also used in other crops, such as wheat (Liu et al., 2010), barley (Wang et al., 2012), sorghum (Shehzad et al., 2009) and corn (Andersen et al., 2007). For salt tolerance related characters, different QTLs were identified in rice, including those on linkage group 1 such as Saltol QTL, QNa, and SKC1/ OsHKT8 - along with QNa:K on linkage group 4. Saltol was involved in ion uptake during salinity stress (Bonilla et al., 2002).

\section{Conclusion}

Salt tolerance is a quantitative character governed by several genes. Poor knowledge about mechanism of its inheritance makes slow progress in its introgression into target crops. Our study showed extensive genetic variation in salt tolerance. Several simple sequence repeat (SSR) markers were identified for salt tolerance related characters, which can be potentially exploited in common sunflower (Helianthus annuus L.) improvement programs via marker-aided selection. Among the various molecular markers, SSR and single nucleotide polymorphism (SNP) markers have received considerable attention, because of co-dominant inheritance. Structure analysis divided the studied population of sunflower into two subpopulations. We presented numerous significant maker-characters associations over the whole sunflower genome. Some markers were associated with characters under both natural and salt stress states. For instance, the SSR markers such as P608, P718, P1265 and P1179 were associated with characters both in natural and salt stress conditions. The genetic relationships between any characters under different conditions were indicative of the presence of common quantitative trait loci (QTL). This further suggested that improving a character under one condition might result in offspring with improved character in other states. Markers with the highest association could be used for saturating linkage maps. Moreover, other physiological and agronomic characters could be studied with SSR markers to make a robust and tolerant plant with high yield.

\section{Acknowledgments}

The authors thank Urmia Institute of Biotechnology for the lab facilities.

Received 10102017

Accepted 27042018

\section{References}

1. Andersen J. R., Zein I., Wenzel G., Krützfeldt B., Eder J., Ouzunova M., Lübberstedt T. 2007. High levels of linkage disequilibrium and associations with forage quality at a phenylalanine ammonia-lyase locus in European maize (Zea mays L.) inbreds. Theoretical and Applied Genetics, 114 (2): 307-319. https://doi.org/10.1007/s00122-006-0434-8

2. Anwar-ul-Haq M., Akram S., Akhtar J., Saqib M., Saqib Z. A., Abbasi G. H., Jan M. 2013. Morphophysiological characterization of sunflower genotypes (Helianthus annuus L.) under saline condition. Pakistan Journal of Agricultural Sciences, 50 (1): 49-54.

3. Arzani A. 2008. Improving salinity tolerance in crop plants: biotechnology view. In Vitro Cellular and Developmental Biology - Plant, 44 (5): 373-383. https://doi.org/10.1007/s11627-008-9157-7
4. Ashraf M. 2004. Some important physiological selection criteria for salt tolerance in plants. Flora-Morphology, Distribution, Functional Ecology of Plants, 199 (5): 361-376. https://doi.org/10.1078/0367-2530-00165

5. Basirnia A., Hatami Maleki H., Darvishzadeh R., Ghavami F. 2014. Mixed linear model association mapping for low chloride accumulation rate in oriental-type tobacco (Nicotiana tabacum L.) germplasm. Journal of Plant Interactions, 9 (1): 666-672. https://doi.org/10.1080/17429145.2014.893453

6. Bonilla P. S., Dvorak J., Mackell D., Deal K., Gregorio G. 2002. RFLP and SSLP mapping of salinity tolerance genes in chromosome 1 of rice (Oryza sativa L.) using recombinant inbred lines. Philippine Agricultural Scientist (Philippines), 85: 68-76.

7. Bradbury P. J., Zhang Z., Kroon D. E., Casstevens T. M., Ramdoss Y., Buckler E. S. 2007. TASSEL: software for association mapping of complex traits in diverse samples. Bioinformatics, 23: 2633-2635. https://doi.org/10.1093/bioinformatics/btm308

8. Breseghello F., Sorrells M. S. 2006. Association mapping of kernel size and milling quality in wheat (Triticum aestivum L.) cultivars. Genetics, 172: 1165-1177. https://doi.org/10.1534/genetics.105.044586

9. Darvishzadeh R. 2016. Population structure, linkage disequilibrium and association mapping for morphological traits in sunflower (Helianthus annuus L.). Biotechnology and Biotechnological Equipment, 30 (2): 236-246. https://doi.org/10.1080/13102818.2015.1136568

10. Evanno G., Regnaut S., Goudet J. 2005. Detecting the number of clusters of individuals using the software STRUCTURE: a simulation study. Molecular Ecology, 14: $2611-2620$

https://doi.org/10.1111/j.1365-294X.2005.02553.X

11. Flowers T. J. 2004. Improving crop salt tolerance. Journal of Experimental Botany, 55 (396): 307-319.

https://doi.org/10.1093/jxb/erh003

12. Flowers T. J., Flowers S. A. 2005. Why does salinity pose such a difficult problem for plant breeders? Agricultural Water Management, 78 (1): 15-24. https://doi.org/10.1016/j.agwat.2005.04.015

13. Gajardo H. A., Wittkop B., Soto-Cerda B., Higgins E. E., Parkin I. A. P., Snowdon R. J, Federico M. L., IniguezLuy F. L. 2015. Association mapping of seed quality traits in Brassica napus L. using GWAS and candidate QTL approaches. Molecular Breeding, 35 (143). https://doi.org/10.1007/s11032-015-0340-3

14. Horie T., Karahara I., Katsuhara, M. 2012. Salinity tolerance mechanisms in glycophytes: an overview with the central focus on rice plants. Rice, 5 (1): 11-29. https://doi.org/10.1186/1939-8433-5-11

15. Hussain M. K., Rehman O. U. 1993. Breeding sunflower for salt tolerance; physiological basis for salt tolerance in sunflower (Helianthus annuus L.). Helia, 16: 77-84.

16. Jun T. H., Van K., Kim M. Y., Lee S. H., Walker D. R. 2008. Association analysis using SSR markers to find QTL for seed protein content in soybean. Euphytica, 162 (2): 179-191. https://doi.org/10.1007/s10681-007-9491-6

17. Liu L., Wang L., Yao J., Zheng Y., Zhao C. 2010. Association mapping of six agronomic traits on chromosome $4 \mathrm{a}$ of wheat (Triticum aestivum L.). Molecular Plant Breeding, 1 (5): 1-10. https://doi.org/10.5376/mpb.2010.01.0005

18. Mackay I., Powell W. 2007. Methods for linkage disequilibrium mapping in crops. Trends in Plant Science, 12 (2): 57-63. https://doi.org/10.1016/j.tplants.2006.12.001

19. Makhdum M. S. A., Ashfaq M. 2008. An economic evaluation of negative impact of water-logging and salinity on wheat productivity. Soil and Environment, 27 (1): 105-108.

20. Mandel J. R., Nambeesan S., Bowers J. E., Marek L. F., Ebert D., Rieseberg L. H., Knapp S. J., Burke J. M. 2013. Association mapping and the genomic consequences of selection in sunflower. PLoS Genetics, 9 (3): e1003378. https://doi.org/10.1371/journal.pgen.1003378

21. Morsali A. F., Darvishzadeh R., Abbaspour N. 2015. Mapping QTLs controlling physiological traits of sunflower under salinity stress. Crop Biotechnology, 10: 1-16.

22. Morsali A. F., Darvishzadeh R., Hatami Maleki H., Barin M., Abbaspour N. 2016. Identification of QTLS controlling yield and yield components in sunflower under salinity stress conditions. Iranian Journal of Filed Crop Science, 47 (1): 87-98. 
23. Nordborg M., Tavare S. 2002. Linkage disequilibrium: what history has to tell us? Trends in Genetics, 18 (2): 83 90. https://doi.org/10.1016/S0168-9525(02)02557-X

24. Oraguzie N. C., Wilcox P. L., Rikkerink E. H. A., de Silva H. N. 2007. Linkage disequilibrium, association mapping in plants. Springer, p. 11-39. https://doi.org/10.1007/978-0-387-36011-9 2

25. Pasda G., Diepenbrock W. 1990. The physiological yield analysis of sunflower. Part II. Climate factors. Fett Wissenschaft Technologie, 93 (5): 155-168. https://doi.org/10.1002/lipi.19910930501

26. Poormohammad Kiani S., Grieu P., Maury P., Hewezi T., Gentzbittel L., Sarrafi A. 2007. Genetic variability for physiological traits under drought conditions and differential expression of water stress-associated genes in sunflower (Helianthus annuus L.). Theoretical and Applied Genetics, 114 (2): 193-207. https://doi.org/10.1007/s00122-006-0419-7

27. Pritchard J. K., Stephens M., Donnelly P. 2000. Inference of population structure using multilocus genotype data. Genetics, 155: 945-959.

28. Rehman O. U., Hussain M. K. 1998. Effect of salinity on growth and development of cultivated sunflower (Helianthus annuus L.). Pakistan Journal of Science, 50: 45-52.

29. Rosenberg N. A., Pritchard J. K., Weber J. L., Cann H. M., Kidd K. K., Zhivotovsky L. A., Feldman M. W. 2002. The genetic structure of human populations. Science, 298 (5602): 2381-2385. https://doi.org/10.1126/science.1078311

30. Saeed M., Wangzhen G., Tianzhen Z. 2014. Association mapping for salinity tolerance in cotton (Gossypium hirsutum L.) germplasm from US and diverse regions of China. Australian Journal of Crop Science, 8 (3): 338-346.

31. Sahranavard A. F., Darvishzadeh R., Ghadimzadeh M. Azizi H., Aboulghasemi Z. 2015. Identification of SSR loci related to some important agro-morphological traits in different oily sunflower (Helianthus annuus L.) lines using association mapping. Crop Biotechnology, 10: 73-87.
32. Schilling E. E. 2006. Helianthus Linnaeus. Flora of North America Editorial Committee (eds). Flora of North America North of Mexico. New York, Oxford, vol. 21, p. 141.

33. Shahbaz M., Ashraf M. 2013. Improving salinity tolerance in cereals. Critical Reviews in Plant Sciences, 32: 237-249. https://doi.org/10.1080/07352689.2013.758544

34. Shehzad T., Iwata H., Okuno K. 2009. Genome-wide association mapping of quantitative traits in sorghum (Sorghum bicolor (L.) Moench) by using multiple models. Breeding Science, 59 (3): 217-227. https://doi.org/10.1270/jsbbs.59.217

35. Snowdon R. J., Fried W. 2004. Molecular markers in brassica oilseed breeding, current status and future possibilities. Plant Breeding, 123 (1): 1-8. https://doi.org/10.1111/j.1439-0523.2003.00968.x

36. Stich B., Melchinger A. E., Frisch M., Maurer H. P., Heckenberger M., Reif J. C. 2005. Linkage disequilibrium in European elite maize germplasm investigated with SSRs. Theoretical and Applied Genetics, 111 (4): 723-730. https://doi.org/10.1007/s00122-005-2057-x

37. Toker C. 2004. Estimates of broad-sense heritability or seed yield and yield criteria in faba bean (Vicia faba L.). Hereditas, 140 (3): 222-225.

https://doi.org/10.1111/j.1601-5223.2004.01780.x

38. Wang M., Jiang N., Jia T., Leach L., Cockram J., Comadran J., Shaw P., Waugh R., Luo Z. 2012. Genomewide association mapping of agronomic and morphologic traits in highly structured populations of barley cultivars. Theoretical and Applied Genetics, 124 (2): 233-246. https://doi.org/10.1007/s00122-011-1697-2

39. Yang G., Zhou R., Tang T., Chen X., Ouyang J., He L., Li W., Chen S., Guo M., Li X., Zhong C., Shi S. 2011. Gene expression profiles in response to salt stress in Hibiscus tiliaceus. Plant Molecular Biology Reporter, 29: 609-617. https://doi.org/10.1007/s11105-010-0267-0

40. Zhao Y. L., Wang H. M., Shao B. X., Chen W., Guo Z. J., Gong H. Y., Sang X. H., Wang J. J., Ye W. W. 2016. SSR-based association mapping of salt tolerance in cotton (Gossypium hirsutum L.). Genetics and Molecular Research, 15 (2). https://doi.org/10.4238/gmr.15027370

ISSN 1392-3196 / e-ISSN 2335-8947

Zemdirbyste-Agriculture, vol. 105, No. 3 (2018), p. 279-286

DOI 10.13080/z-a.2018.105.036

\title{
Nustatytos preliminarios asociacijos tarp paprastosios saulėgrąžos DNR žymeklių ir morfologinių požymių natūraliomis ir druskos streso sąlygomis
}

\author{
S. Ahmadpour ${ }^{1}$, O. Sofalian ${ }^{1}$, R. Darvishzadeh ${ }^{2}$, N. Abbaspour ${ }^{2}$ \\ ${ }^{1}$ Mohaghegh Ardabili universitetas, Iranas \\ ${ }^{2}$ Urmia universitetas, Iranas
}

\begin{abstract}
Santrauka
Dirvožemio druskingumas yra rimta grėsmė žemès ūkio produktyvumui visame pasaulyje. Žemès ūkio biotechnologiju pagrindinis tikslas yra sukurti augalus, pasižyminčius didesniu atsparumu sudetingoms aplinkos sąlygoms, pavyzdžiui, sausrai ir druskingumui. Siekiant pagerinti augalų savybes, pirmasis žingsnis žymekliais pagrịstose selekcijos programose yra asociacijos tarp žymeklio ir požymio nustatymas. Tyrimo metu kiekybiniai požymių lokusai, susiję su atsparumu druskingumui, buvo nustatyti naudojant 84 skirtingos geografinės kilmès paprastosios saulègrąžos (Helianthus annuus L.) inbredines linijas. Linijos buvo identifikuotos su 30 paprastosios pasikartojančios sekos žymeklių. Buvo nustatyta ir įvertinta 71 aiškus fragmentas, iš kurių 87 \% buvo polimorfiški. Asociacijos tarp paprastujų pasikartojančių sekų (PPS) žymeklių ir 18 agronominių savybių analizuoti taikant mišru linijini modelį. PPS žymekliu analizès duomenimis, asociacijų grupe pasidalijo ị dvi subpopuliacijas $(\mathrm{K}=2)$. Iš tirtų PPS žymeklių 435 galimų lokusų porų maždaug 2,06 \% parode esminị sąsajų nesubalansuotumą. Esant natūralioms ir druskos streso sąlygoms, atitinkamai 6 bei 13 PPS lokusu ir vertintu agronominiu savybiu asociacijos buvo esminès $(P \leq 0,01)$. Keletas molekulinių žymeklių buvo esmingai susiję su daugiau nei viena fenotipine savybe; tai rodo galimą genetinės sankibos, arba pleiotropinę, įtaką. Tikimasi, kad nustatyti asociacijas turintys žymekliai bus naudingi vykdant jais pagrisstą atranką paprastosios saulėgrąžos selekcijos programose.
\end{abstract}

Reikšminiai žodžiai: abiotinis stresas, aliejiniai augalai, jungčių nesubalansuotumas, kiekybinis požymių kartografavimas, molekuliniai žymekliai. 